\title{
Gavin Bowd, Paul Morand et la Roumanie
}

\section{Emanuele Kanceff}

\section{(2) OpenEdition}

\section{Journals}

\section{Edizione digitale}

URL: https://journals.openedition.org/studifrancesi/41127

DOI: 10.4000/studifrancesi.41127

ISSN: 2421-5856

\section{Editore}

Rosenberg \& Sellier

\section{Edizione cartacea}

Data di pubblicazione: 1 juillet 2004

Paginazione: 219

ISSN: 0039-2944

\section{Notizia bibliografica digitale}

Emanuele Kanceff, «Gavin Bowd, Paul Morand et la Roumanie», Studi Francesi [Online], 142 (XLVIII | I) |

2004, online dal 30 novembre 2015, consultato il 09 septembre 2021. URL: http://

journals.openedition.org/studifrancesi/41127 ; DOI: https://doi.org/10.4000/studifrancesi.41127

\section{Questo documento è stato generato automaticamente il 9 septembre 2021.}

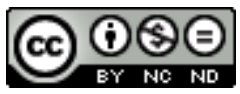

Studi Francesi è distribuita con Licenza Creative Commons Attribuzione - Non commerciale - Non opere derivate 4.0 Internazionale. 


\title{
Gavin Bowd, Paul Morand et la Roumanie
}

\author{
Emanuele Kanceff
}

NOTIZIA

GAVIN BOWD, Paul Morand et la Roumanie, Paris, L'Harmattan, 2002, pp. 154 (Collection

«Espaces Littéraires»).

1 Luogo d'incontro tra Oriente e Occidente, patria della compagna della sua vita, avamposto della civiltà occidentale, la Romania non poteva non lasciare una traccia importante nella vita di Paul Morand, affascinato dal suo carattere ambiguo, vivamente preoccupato per il suo destino tragico. Cittadino del mondo, viaggiatore incallito, Morand soggiornò in Romania in anni cruciali, nella sua qualità di ambasciatore della Francia di Vichy, e poté assistere all'ascesa al potere dei comunisti, alla decimazione dell'élite francofona, rafforzandosi nell'idea premonitrice di una catastrofe cui l'Europa intera sembrava destinata.

2 Su questi presupposti, l'autore studia gli aspetti dell'amicizia franco-rumena, la sua evoluzione nella storia, il dinamismo di simpatia-antipatia che la caratterizza, sul filo conduttore delle concezioni volentieri escatologiche, ma non confermate dalla storia, che Paul Morand ebbe ad esprimere, utilizzando anche testi inediti dello scrittore, come corrispondenza privata, documenti d'archivio del Quai d'Orsay, documenti del Ministero degli Affari esteri di Bucarest. 